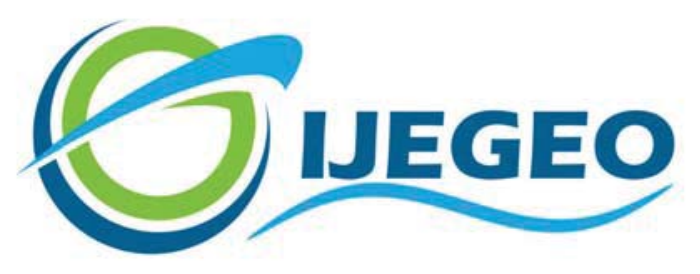

International Journal of Environment and Geoinformatics (IJEGEO) is an international, multidisciplinary, peer reviewed, open access journal.

\title{
Cellular Automata and Markov Chain Based Urban Growth Prediction
}

\author{
Shrushti S. JADAWALA., Shital H. SHUKLA., Poonam S. TIWARI
}

\section{Chief in Editor}

Prof. Dr. Cem Gazioğlu

\section{Co-Editors}

Prof. Dr. Dursun Zafer Şeker, Prof. Dr. Şinasi Kaya,

Prof. Dr. Ayşegül Tanık and Assist. Prof. Dr. Volkan Demir

Editorial Committee (September 2021)

Assoc. Prof. Dr. Abdullah Aksu (TR), Assit. Prof. Dr. Uğur Algancı (TR), Prof. Dr. Bedri Alpar (TR), Assoc. Prof. Dr. Aslı Aslan (US), Prof. Dr. Levent Bat (TR), Prof. Dr. Paul Bates (UK), İrşad Bayırhan (TR), Prof. Dr. Bülent Bayram (TR), Prof. Dr. Luis M. Botana (ES), Prof. Dr. Nuray Çağlar (TR), Prof. Dr. Sukanta Dash (IN), Dr. Soofia T. Elias (UK), Prof. Dr. A. Evren Erginal (TR), Assoc. Prof. Dr. Cüneyt Erenoğlu (TR), Dr. Dieter Fritsch (DE), Prof. Dr. Çiğdem Göksel (TR), Prof.Dr. Lena Halounova (CZ), Prof. Dr. Manik Kalubarme (IN), Dr. Hakan Kaya (TR), Assist. Prof. Dr. Serkan Kükrer (TR), Assoc. Prof. Dr. Maged Marghany (MY), Prof. Dr. Michael Meadows (ZA), Prof. Dr. Nebiye Musaoğlu (TR), Prof. Dr. Masafumi Nakagawa (JP), Prof. Dr. Hasan Özdemir (TR), Prof. Dr. Chryssy Potsiou (GR), Prof. Dr. Erol Sarı (TR), Prof. Dr. Maria Paradiso (IT), Prof. Dr. Petros Patias (GR), Prof. Dr. Elif Sertel (TR), Prof. Dr. Nüket Sivri (TR), Prof. Dr. Füsun Balık Şanlı (TR), Prof. Dr. Uğur Şanlı (TR), Duygu Ülker (TR), Prof. Dr. Seyfettin Taş (TR), Assoc. Prof. Dr. Ömer Suat Taşkın (TR), Assist. Prof. Dr. Tuba Ünsal (TR), Dr. Manousos Valyrakis (UK), Dr. İnese Varna (LV), Dr. Petra Visser (NL), Prof. Dr. Selma Ünlü (TR), Assoc. Prof. Dr. Oral Yağcı (TR), Prof. Dr. Murat Yakar (TR), Assoc. Prof. Dr. İ. Noyan Yılmaz (AU); Assit. Prof. Dr. Sibel Zeki (TR) 


\title{
Cellular Automata and Markov Chain Based Urban Growth Prediction
}

\author{
Shrushti S. Jadawala ${ }^{1}$, (D) Shital H. Shukla ${ }^{1}$, ${ }^{\text {PDoonam S. Tiwari }}{ }^{2}$ iD \\ ${ }^{1}$ Department of Earth Sciences, School of Science, Gujarat University, Ahmedabad, Gujarat 380009,India \\ ${ }^{2}$ Indian Institute of Remote Sensing, Indian Space Research Organization, Department of Space, Government of India, Dehradun 248001, India
}

E-mail: shrushtijadawala@yahoo.com

Received $17 \quad \mathrm{Ag} 2021$ Accepted 22 Feb. 2021

How to cite: Jadawala, et al., (2021). Cellular Automata and Markov Chain Based Urban Growth Prediction, International Journal of Environment and Geoinformatics (IJEGEO), 8(3): 337-343. doi.10.30897/ijegeo.781574

\begin{abstract}
The urban share of the Indian population jumped from 18\% in 1961 to 31.16\% in 2011 (Gupta et.al2013). This huge spurt in growth of the population is putting a huge demand on available land resource. Increasing population results in outward sprawl and growth of the town. This outward growth is causing the transformation of agricultural land and forest land into the habitant areas. An understanding of spatial extent of land cover changes at a regional scale is of great importance since it would facilitate the quantification of changes over a period of time and its analysis in terms of rate of change (Blaschkeet al., 2004; Khanday and Javed, 2009; Yuan et al., 1998). The hybrid Cellular Automata Markov (CA-Markov) method allows multiple classes and can replicate the alteration from one category to another. Thus this hybrid method is an important approach to model both spatial and temporal changes (Eastman, 2006). To predict urban growth in Gandhinagar, LANDSAT Multispectral, TM, ETM+, and OLI/TIRS images for five decades (1972, 1977, 1987, 1994, 2000, 2008, 2015 and 2019) were used for Land use mapping. In the CA Markov model used for the study, Markov Chain Analysis describes land use change from one period to another and was used as the basis to project future changes. The objective of the study was to predict the land cover maps using CA Markov model in the study area, validate the maps by comparing land cover maps produced by image classification and predict future growth scenarios. The land use land cover for the year 2008, 2015 and 2019 are simulated and the simulation results are compared with the actual classified maps of the same years. To assess the accuracy of the predicted maps and validation of the model, several methods were used like calculating agreement and disagreement parameters etc. The LULC for the year 2025 and 2030 were predicted using the model. The results show that from 1972 to 2019 , there is considerable decrease in the cultivated and vegetation cover. This can be attributed to the rapid urban growth in parts of Gandhinagar planning area. Between 1972 and 2019, the urban area has grown significantly by $42 \%$. The major part of urbanization during the mentioned time interval has occurred in the central and western part of the city. On the eastern side the city is bounded by Sabarmati river which has led to urban expansion on the western front.
\end{abstract}

Keywords: Use Land Cover Change (LULC), Operational Land Imager (OLI), Thermal Infrared Sensors (TIRS),

\section{Introduction}

The urbanization process represents a formidable challenge and attracts attention towards cities that are expected to achieve gather more population and supply citizens with proper services in an efficient manner. In India, situation isn't any longer different and therefore the demographic shift has likewise led to an increasing proportion of Indians living in cities. The urban share of the Indian population jumped from $18 \%$ in 1961 to $31.16 \%$ in 2011 (Gupta et al., 2013). This sudden growth within the population is generating the demand of land which ends up in outward growth of the town. This outward growth is causing the transformation of agricultural land and forest land into the habitant areas. This evolution of land is adversely affecting the ecology and environment of that specific area like rise in temperature and global climate change. Hence, urban growth has become a matter of concern for the biological and environmental sustainability. For avoiding things of conurbation, optimum planning is required. Land Cover Land
Use studies are involved in work are numerous and varied, starting from international wildlife to conservation foundations to government researchers and forestry companies (Burak et al., 2004). Although the terms Land Cover and Land Use are often used, their actual meanings are quite different, it's important to explain these differences, and therefore the information which will be as certained from each manner. This study shows the results of a study done to measure the urban sprawl in Gandhinagar city, India through cellular automata CAMarkov model. CA-Markov model can successfully be used to study the urban in rapid changes growing cities. The connection between CA-based urban growth models and GIS provides a concept in urban modeling and expansion in a practical manner providing the possibility.

During the mid-1980s, CA models were proposed as alternative to traditional models due to their simplicity, capability of dynamic spatial simulation and the potential in generating high resolution modelling through the capabilities of GIS and remotely sensed 
data (Torrens and O'Sullivan, 2001). GIS/RS and CAMarkov models are applied to study urban growth patterns the world over; very few studies have applied these methods to examine the urban growth of Gandhinagar. A hybrid model consisting of logistic regression model, Markov chain and cellular automata (CA) was designed to improve the performance of the standard logistic regression model to simulate urban expansion (Jokar et al., 2013). It is depended on specific types and rules entitled land use transformation CAs represent local raster-based simulation for modelling urban expansion for discrete time steps (Shafizadeh Moghadam and Helbich, 2013; Guan et al., 2011). Moreover, GIS can majorly useful to detect and judge the active changes of land use conversion (Celik, et al., 2019; Sekertekin et al., 2016).

At the most rudimentary level a CA is an array (or lattice) of regular cells. At any given time, a particular cell is in one of a finite number of allowed states and its state changes based on the states of its neighbouring cells in the lattice as per a uniformly applied set of transition rules. Cells change their states iteratively and synchronously through the repeated application of these transition rules. CA is thus composed of five principle elements:(i) Lattice: The space in which the cell exists (ii) Cell State: State of the cell out of the given finite number of states (iii) Contiguous Neighbourhood: The cells adjacent to a particular cell (iv) Transition Rule: Transition rules define the state of a given cell in the next time period based on the present state of the cells itself and that of its neighbouring cells (v) Temporal space: Time steps in which CA the evolutes.

The Markov Chain is an adventitious development that illustrates the expectation of one state being change to another state. The Markov Chain built explanatory key output that determines the expectation of change from one category (e.g. agricultural lands) to another category (e.g. built-up), which is called transition probability matrix.

The CA-Markov model does multiple principle evaluation function which combine $\mathrm{CA}$ and Markov Chain modules together. The change that is predicted to achieve through Markov Chain analysis, transition area matrix, CA-Markov appeal a contiguity kernel to 'grow out' a land-use maps to a future time period using a CA function. Therefore, this method is able to move the results of the Markov Chain by CA function to proper outcomes (Pontius et al. 2004a). The reliability and precision of this module will be inspected and indicated. A CA-Markov model is a robust approach in terms of quantity estimation as well as spatial and temporal dynamic modelling of LULCC, because GIS and remote sensing data can be capably incorporated. Biological and social and economic data could be used first to elaborate preliminary conditions, and secondary to specify the Markov-CA model and then to study transition probabilities; and then, to describe the area rules with progress in future maps (Kamusoko et al. 2009). There are several LULC modelling scenarios that have been used in this area, such as the CA model, the Markov Chain, and other approaches; however, in each of these approaches, there is no accurate prediction of future direction. Thus, in this research, CA-Markov model will be used to determine changes in the study area. With the aim of simulating future land-use maps, a set of land-use maps of the study area for 1972-2019 were extracted through Landsat TM, ETM, ETM+ images.

\section{Research Objective}

$\checkmark \quad$ The main objective of the study was to predict the land use land cover maps using CA Markov model in the study area, validate the maps by comparing land cover maps produced by image classification and predict future growth scenarios.

One of the basic objectives of this research is to understand and quantify the temporal and spatial patterns of LULC, as well as model and predict its consequences.

The small objective of this project is also to generate land use/land cover map using different classification methods of remotely sensed data of LANDSAT.

\section{Materials and Methods \\ Study Area}

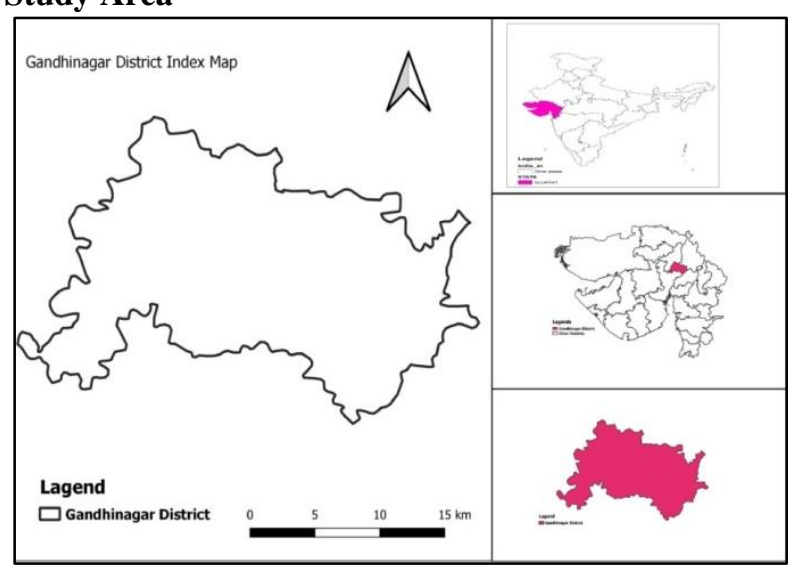

Figure 1: Location Map of Gandhinagar in Gujarat.

Gandhinagar is that the capital city of Gujarat in India and is situated approximately $23 \mathrm{~km}$ north of Ahmedabad, on the west central point of the commercial corridor between Delhi, the political capital of India, and Mumbai, the financial capital of India. Gandhinagar, Gujarat's new capital city, lies on the west geographical area of the Sabarmati River, about $545 \mathrm{~km}$ (338 miles) north of Mumbai, the financial capital of India and $901 \mathrm{~km}$ (560 miles) southwest of Delhi, the political capital. There's a provision of parks, extensive planting and a recreational area along the river giving town a green garden-city atmosphere. Gandhinagar has a mean elevation of $81 \mathrm{~m}$. The town sits on the banks of the Sabarmati River, in north-central-east Gujarat. The $20,543 \mathrm{~km} 2$ area around Gandhinagar is defined by Gujarat capital territory. It spans a part of $205 \mathrm{~km} 2$. The river frequently dries up within the summer, 
leaving only a tiny low stream of water. Gandhinagar is India's tree capital with $54 \%$ green cover on its acreage (Negi, et al., 2019; Panchal et al., 2021; Sutariya et al., 2021).

\section{Methodology}

In this study, satellite image data, ground truth data collected from field was used. The collected data were compiled and analyzed systematically by keeping in view of the objectives of the study. In this study, multispectral sensors, Thematic Mapper, Enhanced Thematic Mapper Plus of Landsat 1,2, 5, \& 8 multispectral digital data (spatial resolution $60 \mathrm{~m}$ ) of winter season of October-1987, November-1987, 2019, December-1972, 2019, Thematic Mapper data (Spatial resolution 30m), Enhanced Thematic mapper Plus data (Spectral resolution $30 \mathrm{~m}$ ) of starting of summer from March-1977, 1994, 2015, April-2000, 2008.

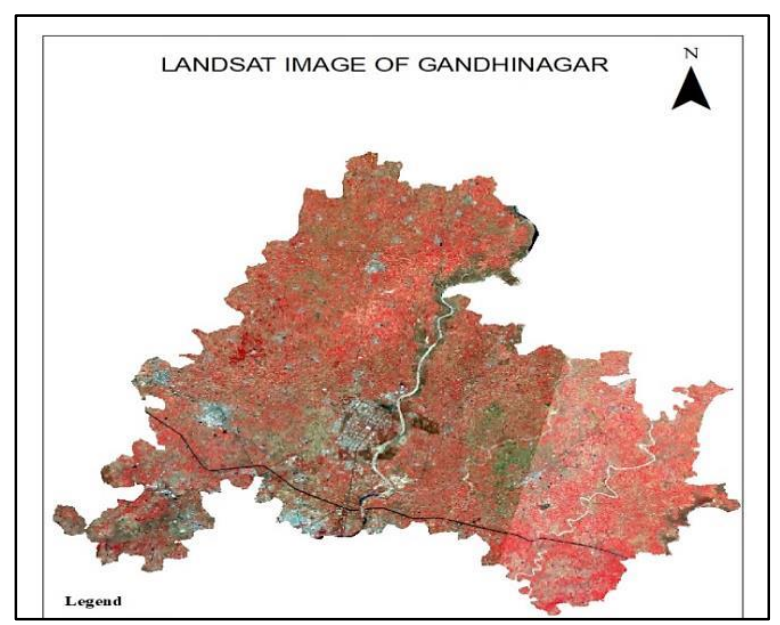

Figure 2: Landsat Multispectral image covering

Gandhinagar area

The identity and site of several the land cover types like urban, agriculture, wetland, are referred to as prior through a mixture of field work and their experiences. The analyst attempts to locate specific sites within the remotely sensed data that represent homogeneous samples of these known land cover types called as training sites. Multivariate statistical parameters are calculated for these training sites. Every pixel both inside and out of doors the training sites is evaluated and assigned to the category of which it's highest likelihood of being member. Supervised classification has been in dire straits preparation of the Land use map. The chosen training classes were completely supported visual interpretation of user. Training sites are the areas, selected by an analyst within the image which is representative of the land cover classes of interest. Nearly 30 sample plots are collected belonging to same land use and land cover categories for each training site which were merged further into single class. The Maximum likelihood classification (MLC) method has been used in the study. In this, the likelihood itself selects the set of values of the model parameters that maximizes the likelihood functions. For improving the classification results recoding has been done. The urban area has been extracted from the land use/land cover maps. By overlaying all extracted urban area, the direction of the growth pattern can be estimated. Different supervised classification methods are used for LULC change detection.

The CA-Markov model could be a multi-criteria evaluation function which integrates CA and Markov Chain modules together. Using the amount of change that is expected to achieve through Markov chain analysis, particularly the transition area matrix, CAMarkov applies a contiguity kernel to grow out a land use map to a later period of your time through a CA function. The knowledge and accuracy of this module are going to be examined and demonstrated. A CAMarkov model may be a robust approach in terms of quantity estimation moreover as spatial and temporal dynamic modeling of LULCC, because GIS and remote sensing data could also be capably incorporated. Biophysical and socio-economic data are often familiar with first define preliminary conditions, and second to parameterize the Markov-CA model then to analyze transition probabilities, and to work out the neighborhoods rules with transition potential maps.

In the CA-Markov model, the Markov Chain manages temporal dynamics among the land use/cover categories, based on transition probabilities, while the spatial dynamics are controlled by local rules determined either by the CA spatial filter or transition potential maps.

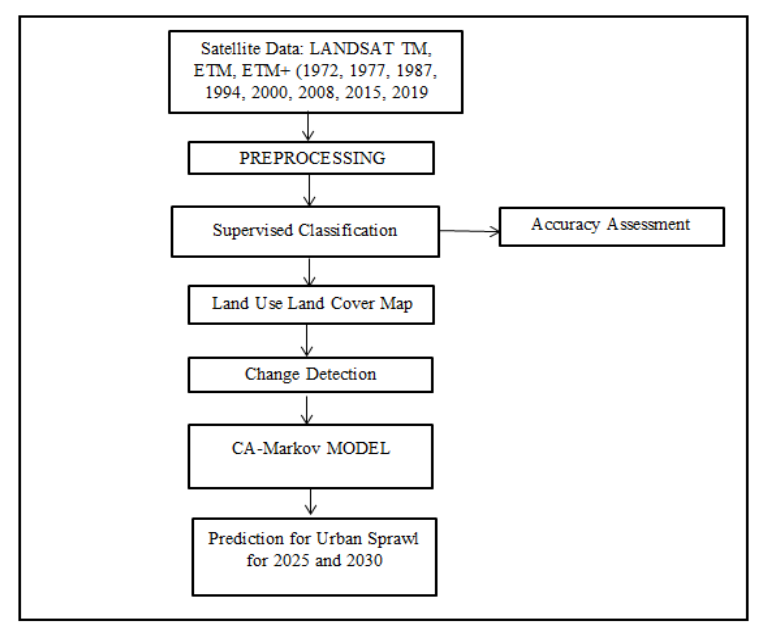

Figure3: Methodology Flow-chart to conduct study 

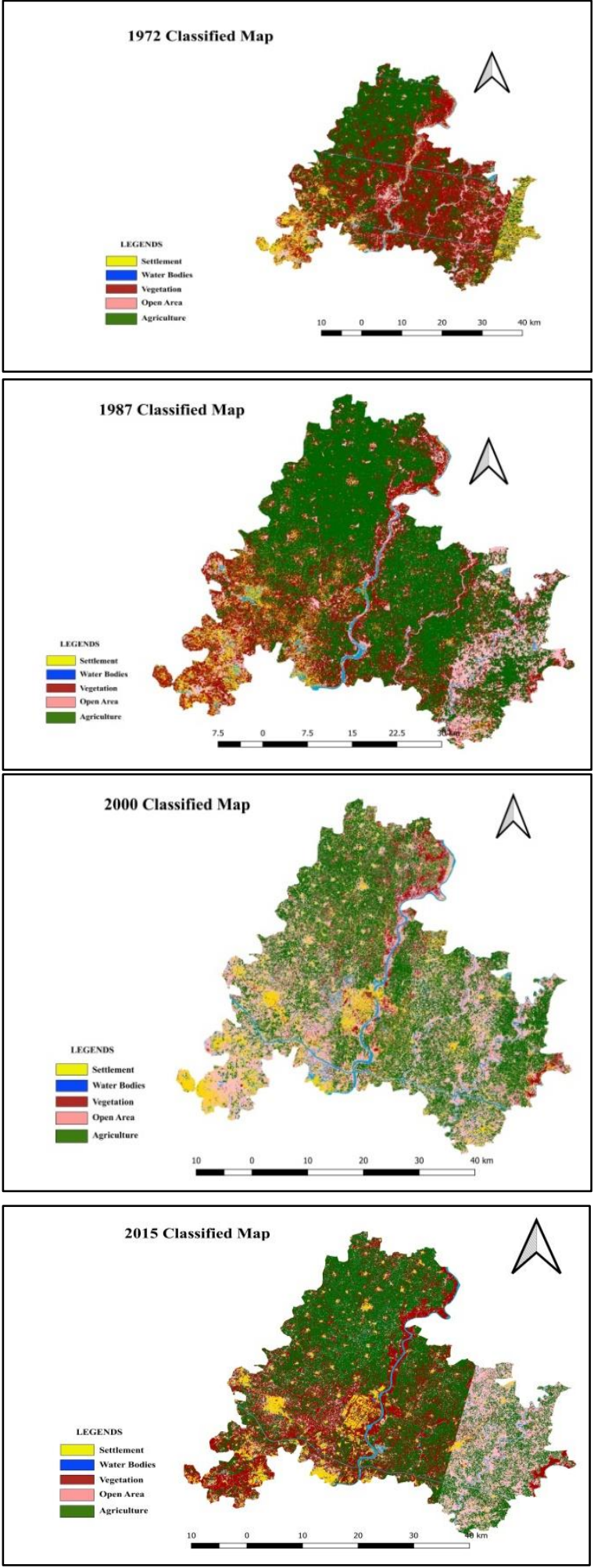

Figure-4: Multi-date classified images generated using Landsat covering Gandhinagar.

Accuracy Assessment is a important part of any classification project. If compares the classified image to another data source that is compared to be accurate. Kappa is used to control only those instances that may have been correctly classified by chance.
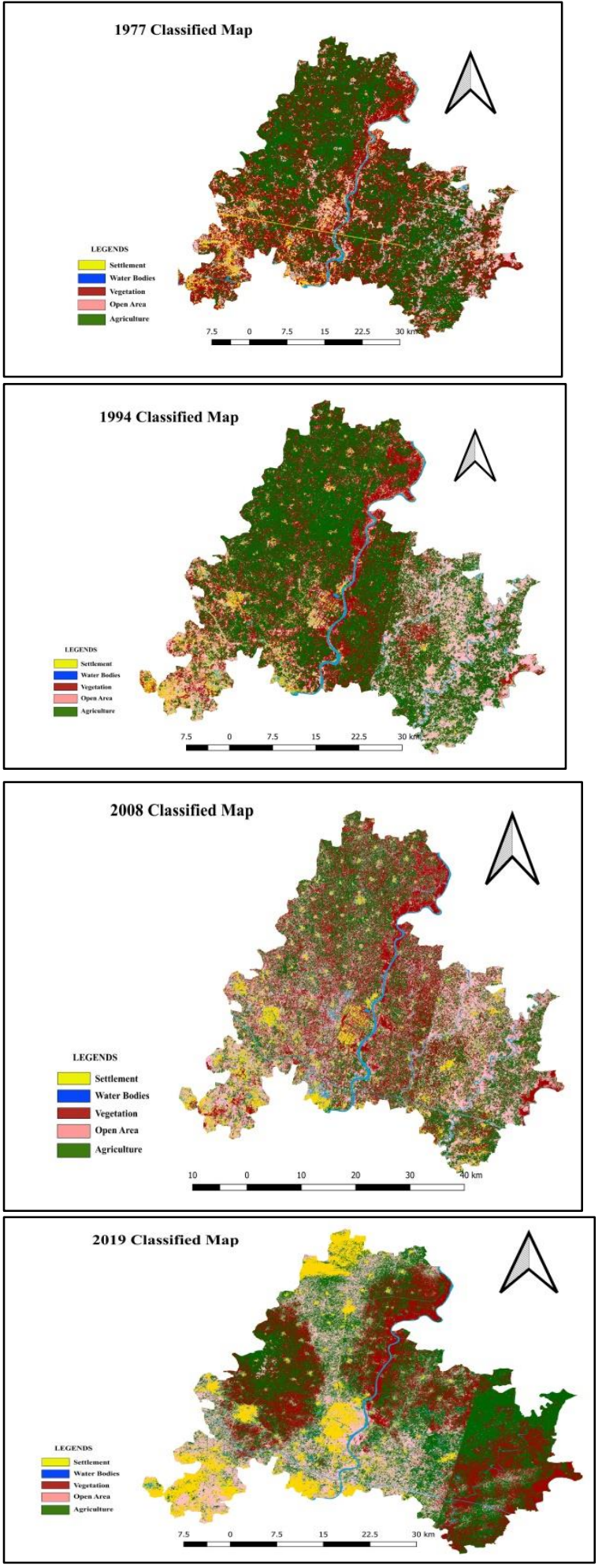
Table 1: Accuracy Assessment for LULC Classification (1972-2019)

\begin{tabular}{cccccc}
\hline S. No. & Year & Kappa Statistics & S. No. & Year & Kappa Statistics \\
\hline 1 & 1972 & 0.8540 & 5 & 2000 & 0.8925 \\
2 & 1977 & 0.7842 & 6 & 2008 & 0.8246 \\
3 & 1987 & 0.9034 & 7 & 2015 & 0.7931 \\
4 & 1994 & 0.8805 & 8 & 2019 & 0.8571 \\
\hline
\end{tabular}

Table 2: Periodical Percentage rate of Change of LULC classes

\begin{tabular}{ccccccccc}
\hline \multirow{2}{*}{ Sr. No. } & \multirow{2}{*}{ Classes } & $(1972-$ & \multirow{2}{*}{$1977-87)$} & \multirow{2}{*}{$(1987-94)$} & $(1994-$ & $(2000-$ & $(2008-$ & $(2015-$ \\
& & & & & $2000)$ & $2008)$ & $2015)$ & $2019)$ \\
\hline 1 & Settlement & 2.27 & 3.23 & 2.14 & 1.94 & 2.22 & 2.98 & 1.14 \\
2 & Waterbodies & 0.00 & 0.02 & 0.01 & 0.07 & 0.45 & 0.22 & 0.17 \\
3 & Vegetation & -0.12 & -3.19 & -1.05 & -2.89 & -0.36 & -3.10 & -1.65 \\
4 & Open Area & 1.35 & 1.90 & 3.31 & 0.20 & 1.11 & 1.10 & 2.12 \\
5 & Agriculture & -0.26 & -0.75 & -0.31 & -0.45 & -0.31 & -0.12 & -0.20 \\
\hline
\end{tabular}

One of the basic objectives of this research is to understand and quantify the temporal and spatial patterns of LULC, as well as model and predict its consequences. An understanding of spatial extent of land cover changes at a regional scale is of great importance since it would facilitate the quantification of changes over a period of time and its analysis in terms of rate of change. Change detection is the process of recognizing variation in the condition of a feature or phenomenon by examining and monitoring it at different time. Change detection in LULC can be executed on yearly basis in an environment which is prone to dynamic Magnitude of change can be assessed by analyzing the areal extent of the change in land cover classes. Five time-sequentially classified images corresponding to 1972 , 1977, 1987, 1994, 2000, 2008, 2015 and 2019 are used to monitor the magnitude of changes in LULC pattern in study area.

Nature of Change is often assessed by analyzing the change trajectories in land cover classes over time. These trajectories are described as trends over time which is responsible for changes in earth resource dynamics in a particular area. These changes occur due to changing circumstances at regional and local level depending upon various factors. The generic pattern of change can be identified as a sequence of land use changes over an area. In this study, trajectories of landcover change are generated which refer to successive land-cover types for a given pixel over period of observation. The post classification change detection results in a category wise map which denotes the landcover classes at the two period of time for every pixel. These "from" and "to" identifiers enable the definition of logical land-cover change trajectory. Land Cover changes in an area are generally discrete, which result in complex landscape and mixed cover types (Clarke et al., 1997). It is crucial to amalgamate this complexity into the investigation of land-cover-change processes so that a better understanding regarding causes of change is achieved and acquire improved ability to predict likely changes. The change trajectories may be categorized into three generic classes namely unchanged, stable changes and unstable changes.
Temporal change trajectories were generated for every class to assess the spatial pattern of change within the area. Figure - depicts temporal change trajectories for LULC classes.

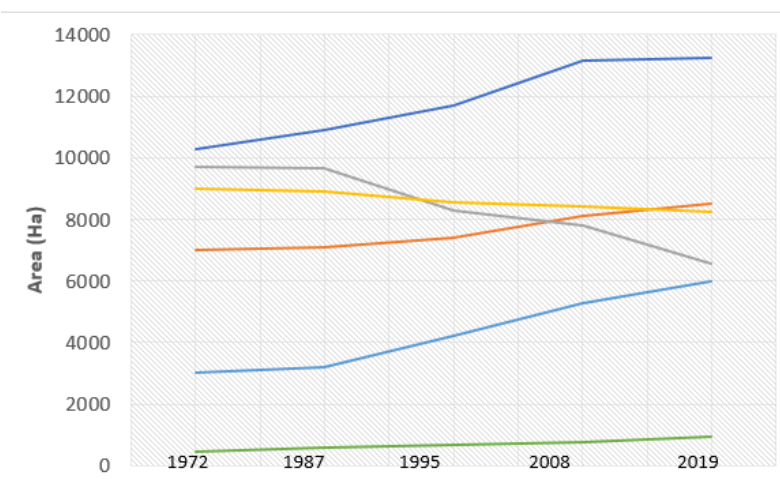

Figure 5: Temporal Change Trajectories for LULC classes

\section{Conclusion}

The main objective of this project is to generate land use/land cover map using different classification methods of remotely sensed data of LANDSAT. Image classification method is being carried out by digitizing the image, and it has been done to identify the different features. For digitization and classification our area of interest is GANDHINAGAR in Gujarat state and the major classes identified are Settlement, Water bodies, Vegetation, Open area, Agriculture. Moreover, supervised classification easily helps to identify the major features helps us to determine the healthy vegetation, urban growth sprawl, etc. In this step the simulated outcome is compared with the referenced map. For the simulated land use/cover maps for 19722019 were compared with the actual satellite-derived land use/cover maps of 1972-2019 based on the Kappa statistic with GIS software using the land use maps for 1972-2019. The results attained from model calibration were evaluated using Kappa coefficient. The statistics indicate how well the comparison map agrees with the reference map. Its value varies between $0-1$. The value 1 indicates the perfect matching of simulated and the reference map and vice versa. 
Land use land cover mapping and change detection have increasingly been recognized as one of the most effective tools for environmental resource management. It can be concluded from the results that, till the year 2019 even in future, there will be considerable decay in the agricultural and vegetation because of the rapid urban growth in parts of Gandhinagar planning area. The results show that from 1972 to 2019, there is considerable decrease in the cultivated and vegetation cover. This can be attributed to the rapid urban growth in parts of Gandhinagar planning area. Between 1972 and 2019, the urban area has grown significantly by $42 \%$. The major part of urbanization during the mentioned time interval has occurred in the central and western part of the city. On the eastern side the city is bounded by Sabarmati River which has led to urban expansion on the western front.

In future work, vegetation and water bodies area should be remain same or increase to maintain economic and ecological parameters, which is our main objective. On the other side sudden growth in settlement is also an increase in development, though urban growth is good but urban sprawl is a big issue these days.

\section{Acknowledgements}

The study is a part of my M.Sc. (Geoinformatics) programme. This work has been done in collaboration with Department of Earth Sciences, Gujarat University and Geoweb services, Information Technology, and Distance learning Department (GIT/DL), Indian Institute of Remote Sensing (IIRS-ISRO), Dehradun, India. Author is grateful to Dr. Poonam S. Tiwari (Scientist/Engineer -'SF', IIRS, Dehradun), Dr. Shital Shukla (Head of Department, Department of Earth Sciences, Gujarat University) and acknowledged for the technical and overall support in the study. We, also grateful to the GIT/DL Department of IIRS-ISRO, Dehradun for providing lab facilities like software and other technical requirements.

\section{References}

Albizua, L., Donezar, U., \& Ibáñez, J. C. (2012). Monitoring urban development consolidation for regional management on water supply using remote sensing techniques. European Journal of Remote Sensing, 45(1), 283-292.

Anane, M., Bouziri, L., Limam, A., Jellali, S. (2012). Ranking suitable sites for irrigation with reclaimed water in the Nabeul-Hammamet region (Tunisia) using GIS and AHP-multicriteria decision analysis. Resources, Conservation and Recycling, $65,36-46$.

Arsanjani, J. J., Helbich, M., Kainz, W., Boloorani, A. D. (2013). Integration of logistic regression, Markov chain and cellular automata models to simulate urban expansion. International Journal of Applied Earth Observation and Geoinformation, 21, 265-275.
Barredo, J. I., Demicheli, L., Lavalle, C., Kasanko, M., McCormick, N. (2004). Modelling future urban scenarios in developing countries: an application case study in Lagos, Nigeria. Environment and Planning B: Planning and Design, 31(1), 65-84.

Batty, M. (1967). Urban Development on the Desktop: Simulation with the Use of Extended Cellular Automata. Environment and Planning A, 30, 1943.

Batty, M., Xie, Y. (1994). Modelling inside GIS: Part 1. Model structures, exploratory spatial data analysis and aggregation. International Journal of Geographical Information Systems, 8(3), 291-307.

Batty, M., Xie, Y. (1994). Modelling inside GIS: Part 2. Selecting and calibrating urban models using ARC-INFO. International Journal of Geographical Information Systems, 8(5), 451-470.

Batty, M., Xie, Y. (1997). Possible urban automata. Environment and Planning B: Planning and Design, 24(2), 175-192.

Burak, S., Dogan. E., Gazioglu. C. (2004). Impact of Urbanization Andtourism On Coastal Environment. Ocean and Coastal Management. 47: 515-527

Cabral, P., Zamyatin, A. (2009). Markov processes in modeling land use and land cover changes in Sintra-Cascais, Portugal. Dyna, 76(158), 191-198.

Celik, B., Kaya, Ş., Alganci, U., Seker, DZ. (2019). Assessment of the relationship between land use/cover changes and land surface temperatures: a case study of thermal remote sensing, FEB Fresenius Environ. Bull., 3, 541

Clarke, K. C., Hoppen, S., Gaydos, L. (1997). A selfmodifying cellular automaton model of historical urbanization in the San Francisco Bay area. Environment and planning B: Planning and design, 24(2), 247-261.

Falahatkar, S., Soffianian, A. R., Khajeddin, S. J., Ziaee, H. R., Nadoushan, M. A. (2011). Integration of Remote Sensing data and GIS for Prediction of Land cover map. International journal of Geomatics and Geosciences, 1(4), 847.

Gupta, K. (2013). Unprecedented growth of Dehradun urban area: a spatio-temporal analysis. International Journal of Advancement in Remote Sensing, GIS and Geography, 1(2), 47-56.

Guzman, L. A., Escobar, F., Peña, J., Cardona, R. (2020). A cellular automata-based land-use model as an integrated spatial decision support system for urban planning in developing cities: The case of the Bogotá region. Land use policy, 92, 104445.

Houet, T., Hubert-Moy, L. (2006). Modeling and projecting land-use and land-cover changes with Cellular Automaton in considering landscape trajectories. EARSeL eProceedings, 5(1), 63-76.

Houet, T., Loveland, T. R., Hubert-Moy, L., Gaucherel, C., Napton, D., Barnes, C. A., Sayler, K. (2010). Exploring subtle land use and land cover changes: a framework for future landscape studies. Landscape Ecology, 25(2), 249-266.

Kamusoko C, Aniya M, Adi B, Manjoro M (2009) Rural sustainability under threat in Zimbabwesimulation of future land use/cover changes in the 
Bindura District based on the markov-cellular automata model. Appl Geogr 29(3):435-447

Jacob, N., Krishnan, R., Harmsen, K., Murali Krishna, I. V. (2006). Spatial dynamic modeling through cellular automata for simulating land use change dynamics. International Journal of Geoinformatics, 2(2), 31-38.

Jain, S., Siddiqui, A., Tiwari, P. S., Shashi, M. (2016). Urban growth assessment using CA Markov model: A case study of Dehradun City. 9th International Geographic Union. Khatai, A. K. To Assess the Impact of Land Use and Climate change on Streamflow of Upper Baitarani River Basin.

Jokar Arsanjani J, Helbich M, Kainz W, Bloorani A D 2013b Integration of logistic regression, Markov chain and cellular automata models to simulate urban expansion. International Journal of Applied Earth Observations and Geoinformation 21: 26575

Lahti, J. (2008). Modelling urbain growth using cellular automata: a case study of Sydney, Australia. ITC.

Maithani, S. (2010). Cellular automata based model of urban spatial growth. Journal of the Indian Society of Remote Sensing, 38(4), 604-610.

Maithani, S. (2010). Cellular automata based model of urban spatial growth. Journal of the Indian Society of Remote Sensing, 38(4), 604-610.

Negi, S., Arya, A., Kathota, J., Patel, A., Singh, V., Garg, J., Kalubarme, M. (2019). Analysis of impact of Canal Irrigation on Waterlogged areas and Environment using Geo-informatics Technology in Gujarat State. International Journal of Environment and Geoinformatics, 6(2), 172185, doi. 10.30897 /ijegeo.541714

Nouri, J., Gharagozlou, A., Arjmandi, R., Faryadi, S., Adl, M. (2014). Predicting urban land use changes using a CA-Markov model. Arabian Journal for Science and Engineering, 39(7), 5565-5573.

Panchal, J., Shukla, S., Kalubarme, M. (2021). Analysis of Optimum Growth Stages for Winter Crop Separability using Multi-Temporal NDVI Profiles in Vijapur Taluka, Gujarat State. International Journal of Environment and Geoinformatics, 8(2), 135-143, doi. 10.30897/ijegeo.803303.

Pontius Jr, R. G., Schneider, L. C. (2001). Land-cover change model validation by an ROC method for the Ipswich watershed, Massachusetts, USA. Agriculture, ecosystems \& environment, 85(1-3), 239-248.

Pontius Jr, R. G., Huffaker, D., Denman, K. (2004). Useful techniques of validation for spatially explicit land-change models. Ecological modelling, 179(4), 445-461.

Shafizadeh Moghadam, H., Helbich, M. (2013). Spatiotemporal urbanization processes in the megacity of Mumbai, India: a Markov chainscellular automata urban growth model, Appl. Geogr., 40, 140-149, 10.1016/j.apgeog.2013. 01.009 .
Sekertekin, A., Kutoglu, S.H.; Kaya, Ş. (2016). Evaluation of spatio-temporal variability in land surface temperature: A case study of Zonguldak, Turkey. Environ. Monit. Assess, 188, 30.

Sutariya, S.,Hirapara, A., Meherbanali, M., Tiwari, M., Singh, V., Kalubarme, M. (2021). Soil Moisture Estimation using Sentinel-1 SAR Data and Land Surface Temperature in Panchmahal District, Gujarat State. International Journal of Environment and Geoinformatics, 8(1), 65-77, doi. 10. 30897/ijegeo.777434.

Torrens, PM., O’Sullivan, D. (2001). Cellular automata and urban simulation: where do we go from here? Environment and Planning B: Planning and Design, 28, 163-168 